Ann. rheum. Dis. (1955), 14, 278.

\title{
PARAFFIN-WAX BATHS IN THE TREATMENT OF RHEUMATOID ARTHRITIS
}

\author{
BY \\ R. HARRIS AND J. B. MILLARD \\ From the Department of Physical Medicine and Rehabilitation, Devonshire Royal Hospital, Buxton
}

(RECEIVED FOR PUBLICATION MARCH 10, 1955)

The physical treatment most frequently used for the hands in rheumatoid arthritis is the local paraffinwax bath. It was first described by Humphris (1919) and since then has been in general use. The standard textbooks of physical medicine and rheumatology refer to wax baths as being of value, but we have been unable to find any critical attempt to assess this. It is unusual for a patient with rheumatoid arthritis to be admitted to this hospital who has not received prolonged courses of paraffinwax baths at other hospitals, usually in the outpatient department. Wax baths are also extensively used at the Devonshire Royal Hospital, approximately 10,000 individual wax treatments being given each year.

Although evaluating the effect of any form of therapy in rheumatoid arthritis is notoriously difficult, especially if dramatic results cannot be expected, it was decided to investigate the progress of the hands treated with paraffin wax, and compare them with those of an untreated series of patients.

\section{Method}

Ninety successive in-patients with rheumatoid arthritis referred to the physiotherapy department for paraffinwax hand baths were divided into three groups, the choice being made at random by the department clerk. Group I received no local treatment to the hands, Group II had wax baths daily for 3 weeks, and Group III had wax baths daily for 6 weeks. The patients were unselected, except that subjects who had recently taken, or were taking, cortisone or ACTH were excluded from the investigation.

All patients were taking calcium aspirin gr. 10-15 three times a day during their trial period. They received no other local treatment to the hands during the trial period, but they were all carrying out a general programme of physical rehabilitation linked with the activity of their disease.

The method of applying the wax was by the patient dipping both hands into the bath of melted wax (at $110^{\circ}-115^{\circ} \mathrm{F}$.) six times, so forming a glove of wax. The $\overrightarrow{\vec{t}}$ hands were then wrapped in a layer of greaseproof paperis and two towels, which were retained for 20 minutes $\infty$ After this, supervised finger exercises were performedo Group I patients did no finger exercises, and Group IP subjects discontinued them after the third week.

Skin temperature measurements, using the Cambridge skin thermometer, were taken of the pulp of the middle्ष finger and the skin of the dorsum of the third metacarpaB head in six subjects, before, immediately on withdrawing the hands from the wax baths, and at 10-minute intervals. for a further 60 minutes.

When the hands were withdrawn from the wax both the thermocouples were inserted under the wax contact with the hand, and cooling curves plotted. rise in temperature was similar in the same hand at botts sites. The range of temperature rise was from $2.9 \overline{0}$ $9 \cdot 5^{\circ} \mathrm{C}$. (mean $5 \cdot 8^{\circ}$ ). Skin temperature rapidly fell to̊ initial values or below within a time range of $10-60$ min尺 (mean 37). It is clear that with the technique employed a fair rise of temperature is obtained, but is not long maintained.

The hands were examined by a team of assessorsyy one of them (J.B.M.) being present on every occas sion. The subjects were initially examined or 2 successive days before admission to the treatment scheme, and the mean of these readings used to give an initial base line. They were further examined weekly for 6 weeks. All assessments of the same patient were carried out on the same day of the weep and at the same time of day. A special proforma. was used. The duration of disease, stage and funco tional grade of the disease (Steinbrocker and others 1949), erythrocyte sedimentation rate (Westergren) local deformity of the hands, and general treatmen $\psi^{2}$ were noted. The local assessment was comprehen? sive, including examination of every joint in the han The distal phalanges of all the fingers were considere $\$$ as a single joint for record purposes, as was the wrist' joint. 
The following data were recorded serially for each joint of the hand:

(1) Tenderness

(a) Clinical impression, by finger pressure, graded 0-3 in order of increasing severity.

(b) Pressure pain, with an algesiometer, recorded in lb. (Janus, 1950).

(2) Pain, graded 0-3 in order of increasing severity

(a) at rest;

(b) on movement.

(3) Swelling

(a) Clinical impression, graded $0-3$ in order of increasing severity.

(b) Circumference of proximal interphalangeal joints, measured by ring sizes.

Total hand function was measured separately for each hand by the following tests:

(1) Grip

(a) Clinical impression by hand grip, graded 0-3 $(0=$ normal, 1 fair, 2 poor, 3 absent $)$.

(b) Rubber bag ergometer; sustained height in $\mathrm{mm}$. Hg.

(2) Dexterity

(a) Number of beads picked up and placed in a standard container in $30 \mathrm{sec}$.

(b) Distance thread of a standard screw could be turned in $15 \mathrm{sec}$.

At the third and sixth weeks the assessment team, using all the collected data, arrived at an overall impression of the patients' progress both in general condition and in the hands. At the sixth week the patients also recorded their own total impression of their hands. These were recorded as:

$$
\begin{aligned}
-1 & =\text { worse } \\
0 & =\text { no change } \\
1 & =\text { slight gain } \\
2 & =\text { moderate gain; } \\
3 & =\text { major gain. }
\end{aligned}
$$

During their trial period nineteen of the subjects left the series owing to discharge from hospital or other reasons; three of the 19 had developed wax rashes. A total of 71 subjects completed the full 6 weeks' observation period. The withdrawals affected the size of the groups about equally, and Table I shows that it is unlikely that they would have altered the final results in any way.

\section{Results}

The three groups were roughly matched in numbers, age distribution, stage of disease, and general progress. The relevant data is incorporated in Table II, which also includes alterations in the erythrocyte sedimentation rate. These are graded -1 to 3 :

$$
\begin{aligned}
-1 & =\text { increased; } \\
0 & =\text { no change; } \\
1 & =\text { decrease of less than } 20 \mathrm{~mm} . ; \\
2 & =\text { decrease } 20-40 \mathrm{~mm} . ; \\
3 & =40 \mathrm{~mm} . \text { or more. }
\end{aligned}
$$

\begin{tabular}{|c|c|c|c|c|c|c|c|c|c|c|c|c|c|c|c|c|c|c|c|c|c|c|c|c|c|}
\hline \multirow{3}{*}{ Group } & \multirow{3}{*}{$\begin{array}{l}\text { No. } \\
\text { of } \\
\text { Sub- } \\
\text { jects }\end{array}$} & \multirow{2}{*}{\multicolumn{2}{|c|}{ Sex }} & \multirow{3}{*}{$\begin{array}{c}\text { Mean } \\
\text { Age } \\
\text { (yrs) }\end{array}$} & \multirow{3}{*}{$\begin{array}{c}\text { Mean } \\
\text { Dura- } \\
\text { tion of } \\
\text { Disease } \\
\text { (yrs) }\end{array}$} & \multicolumn{8}{|c|}{ Disease } & \multirow{2}{*}{\multicolumn{6}{|c|}{ Assessment at 3 weeks }} & \multirow{2}{*}{\multicolumn{6}{|c|}{ Week of Withdrawal }} \\
\hline & & & & & & \multicolumn{4}{|c|}{ Stage } & \multicolumn{4}{|c|}{ Grade } & & & & & & & & & & & & \\
\hline & & IVI. & $\mathrm{r}$ & & & 1 & 2 & 3 & 4 & 1 & 2 & 3 & 4 & $\overline{-1}$ & 0 & 1 & 2 & 3 & - & 0 & 1 & 2 & 3 & 4 & 5 \\
\hline I & 7 & 1 & 6 & 49 & $2 \frac{1}{2}$ & 5 & 2 & - & - & 2 & 5 & $\overline{-}$ & $\overline{-}$ & - & 2 & 2 & 2 & - & 1 & - & 1 & - & 4 & 2 & - \\
\hline II & 5 & 1 & 4 & 44 & $4 \frac{1}{2}$ & 4 & 0 & 1 & $\overline{-}$ & 1 & 4 & - & $\overline{-}$ & - & 1 & 3 & 1 & - & - & 0 & 0 & 0 & 2 & 2 & 1 \\
\hline III & 7 & 2 & 5 & 51 & 4 & 4 & 2 & 1 & - & 0 & 6 & 1 & - & - & 1 & 2 & 2 & - & 2 & - & 2 & 0 & 1 & 2 & 2 \\
\hline
\end{tabular}

\begin{tabular}{|c|c|c|c|c|c|c|c|c|c|c|c|c|c|c|c|c|c|c|c|c|c|c|c|c|c|}
\hline \multirow{3}{*}{ Group } & \multirow{3}{*}{$\left|\begin{array}{c}\text { Total } \\
\text { No. } \\
\text { of } \\
\text { Sub- } \\
\text { jects }\end{array}\right|$} & \multicolumn{2}{|c|}{ Sex } & \multirow{3}{*}{$\begin{array}{c}\text { Mean } \\
\text { Age } \\
(\mathrm{yrs})\end{array}$} & \multirow{3}{*}{$\begin{array}{c}\text { Mean } \\
\text { Dura- } \\
\text { tion of } \\
\text { Disease } \\
(y r s)\end{array}$} & \multicolumn{8}{|c|}{ Disease } & \multirow{2}{*}{\multicolumn{5}{|c|}{$\begin{array}{l}\text { General } \\
\text { Progress }\end{array}$}} & \multirow{2}{*}{\multicolumn{5}{|c|}{$\begin{array}{c}\text { Change in } \\
\text { Erythrocyte } \\
\text { Sedimentation Rate* }\end{array}$}} & \multirow{2}{*}{\multicolumn{2}{|c|}{$\underset{(\mathrm{mm} . / \mathrm{hr})}{\text { E.S.R. (Westergren) }}$}} \\
\hline & & & & & & \multicolumn{4}{|c|}{ Stage } & \multicolumn{4}{|c|}{ Grade } & & & & & & & & & & & & \\
\hline & & IVI. & 1. & & & 1 & 2 & 3 & 4 & 1 & 2 & 3 & 4 & -1 & 0 & 1 & 2 & 3 & -1 & 0 & 1 & 2 & 3 & Initial & Final \\
\hline I & 23 & 4 & 19 & 46 & 7 & 11 & 8 & 4 & - & 6 & 16 & 1 & - & 3 & 8 & 12 & - & - & 6 & 5 & 11 & - & - & 46 & 42 \\
\hline II & 25 & 9 & 16 & 50 & $7 \cdot 4$ & 8 & 11 & 6 & - & 2 & 21 & 2 & - & 4 & 4 & 17 & - & - & 9 & 4 & 10 & - & - & 44 & 46 \\
\hline III & 23 & 4 & 19 & 48 & $8 \cdot 5$ & 5 & 11 & 7 & - & 2 & 16 & 5 & - & 3 & 7 & 13 & - & - & 6 & 4 & 9 & - & - & 50 & 52 \\
\hline
\end{tabular}

In no subject did the erythrocyte sedimentation rate return to normal.

TABLE I

PARTICULARS OF NINETEEN WITHDRAWALS

TABLE II

DETAILS OF THREE GROUPS INVESTIGATED 
The results of the individual methods of assessment do not appear to be worth reporting in full detail. In many the alterations observed week by week were so small that no useful information could be recorded (e.g. joint deformity). Quite commonly a change in one joint would be accompanied by a change in the opposite direction in another joint of the same hand, so that the composite picture appeared unchanged.

As wax baths are usually considered to relieve pain and tenderness and reduce swelling (Kovács, 1945), the results obtained with some tests for these are reported. The strength of grip is frequently used in assessing progress in rheumatoid arthritis and these results are also included.

The figures for "pain" were reached by adding the numerical grade (0-3) of pain on movement for each joint of the hand, giving a composite figure for each hand at each particular examination. The average of both hands was recorded, and the mean weekly values of these figures, as found for each of the three groups, are given in Table III.

Values of "tenderness" were similarly recorded. The size of ring fitting each proximal interphalangeal joint was added, and the average value of each pair of hands gave a composite figure. The mean value was recorded weekly for each group.

Strength of grip (in $\mathrm{mm}$. $\mathrm{Hg}$ ) and "dexterity" (number of beads picked up in the standard time) were measured for each pair of hands, the average figure being recorded. The weekly group mean values are given in Table III.
The final column in Table III shows the numerical difference between the initial and final mean values for each particular test, and is thus a measure of $\frac{\omega}{}$. progress made in the 6 weeks.

Table III indicates that initially Group I was as less severely affected group than the others. At theo end of 3 weeks all three groups had made similar $\frac{\bar{\sigma}}{\bar{E}}$ subjective and objective progress, the difference $\frac{\bar{\rho}}{\vec{D}}$ between actual "scores" reflecting their initial values. $\stackrel{\square}{\varrho}$ At 6 weeks our more objective tests (swelling, grip, dexterity) show very similar progress in all groups, $\overrightarrow{0}$ and so do the subjective tests for Groups I and III. However, in comparison, Group II has made little $\vec{\omega}$ progress and appears to have deteriorated sharply between the fifth and sixth weeks.

These results as a whole fail to show that our $\vec{a}$ subjects gained any benefit from their course of $\frac{\vec{\omega}}{\vec{\phi}}$ wax baths.

Table IV (opposite) shows the overall assessments $D_{0}$ at 3 and 6 weeks respectively: At 3 weeks the three윽 groups are almost identical; at 6 weeks the groups are again similar, although Group II is slightly the $\%$ worse, and Group III slightly the best of the three.

By 3 weeks more than 50 per cent. of the patients $\frac{\mathbb{D}}{3}$ had improved a little, and the improvement was rather more pronounced in the wax-treated groups. By the sixth week there was a further improvemeng, $\vec{c}$ mainly in Groups I and III, and in these 65 at or 73.8 per cent. respectively showed improvemef In Group III no patients were worse than before? treatment, and 30.4 per cent. had made "a moderate

TABLE III

MEAN WEEKLY VALUES OF TESTS FOR PAIN, TENDERNESS, SWELLING, GRIP, AND DEXTERITY

\begin{tabular}{|c|c|c|c|c|c|c|c|c|c|c|c|c|}
\hline Test & & & Week & & 0 & 1 & 2 & 3 & 4 & 5 & 6 & $\begin{array}{c}\text { Total } \\
\text { Change }\end{array}$ \\
\hline \multirow{3}{*}{ Pain } & \multirow{3}{*}{$\ldots$} & \multirow{3}{*}{. } & \multirow{3}{*}{ Group } & I & $1 \cdot 2$ & $1 \cdot 0$ & $1 \cdot 1$ & 0.4 & 0.4 & $0 \cdot 3$ & $0 \cdot 3$ & $0 \cdot 86$ \\
\hline & & & & II & $1 \cdot 9$ & $1 \cdot 5$ & $1 \cdot 1$ & $1 \cdot 2$ & $1 \cdot 3$ & $1 \cdot 3$ & $1 \cdot 6$ & $0 \cdot 28$ \\
\hline & & & & III & $1 \cdot 8$ & $1 \cdot 7$ & $1 \cdot 3$ & $1 \cdot 0$ & $1 \cdot 0$ & $1 \cdot 3$ & 0.9 & 0.87 \\
\hline \multirow{3}{*}{\multicolumn{2}{|c|}{ Tenderness }} & \multirow{3}{*}{. } & \multirow{3}{*}{ Group } & I & $8 \cdot 9$ & $8 \cdot 2$ & $8 \cdot 0$ & $7 \cdot 1$ & $6 \cdot 1$ & $6 \cdot 6$ & $5 \cdot 8$ & $3 \cdot 1$ \\
\hline & & & & II & $11 \cdot 0$ & $11 \cdot 4$ & $8 \cdot 9$ & $9 \cdot 0$ & $10 \cdot 5$ & $9 \cdot 0$ & $10 \cdot 4$ & 0.6 \\
\hline & & & & III & $11 \cdot 9$ & $10 \cdot 6$ & $10 \cdot 6$ & $9 \cdot 4$ & $8 \cdot 7$ & $8 \cdot 7$ & $7 \cdot 2$ & $4 \cdot 7$ \\
\hline \multirow{3}{*}{ Swelling } & \multirow{3}{*}{$\cdots$} & \multirow{3}{*}{. } & \multirow{3}{*}{ Group } & I & $3 \cdot 5$ & $3 \cdot 4$ & $3 \cdot 3$ & $3 \cdot 2$ & $3 \cdot 3$ & $3 \cdot 4$ & $3 \cdot 3$ & 0.22 \\
\hline & & & & II & $4 \cdot 8$ & $4 \cdot 8$ & $4 \cdot 8$ & $4 \cdot 7$ & $4 \cdot 8$ & $4 \cdot 8$ & $4 \cdot 7$ & $0 \cdot 16$ \\
\hline & & & & III & $4 \cdot 1$ & $4 \cdot 1$ & $4 \cdot 0$ & $4 \cdot 1$ & $3 \cdot 9$ & $3 \cdot 9$ & $3 \cdot 9$ & $0 \cdot 15$ \\
\hline \multirow{3}{*}{ Grip } & \multirow{3}{*}{$\cdots$} & \multirow{3}{*}{$\cdots$} & \multirow{3}{*}{ Group } & I & 110 & 119 & 118 & 121 & 127 & 121 & 128 & 18 \\
\hline & & & & II & 105 & 119 & 124 & 116 & 118 & 120 & 116 & 11 \\
\hline & & & & III & 79 & 79 & 86 & 84 & 93 & 89 & 91 & 12 \\
\hline \multirow{3}{*}{ Dexterity } & \multirow{3}{*}{$\cdots$} & \multirow{3}{*}{$\cdots$} & \multirow{3}{*}{ Group } & I & 31 & 34 & 33 & 34 & 34 & 34 & 35 & 4 \\
\hline & & & & II & 28 & 30 & 32 & 31 & 32 & 32 & 33 & 5 \\
\hline & & & & III & 26 & 29 & 31 & 29 & 30 & 31 & 31 & 5 \\
\hline
\end{tabular}


TABLE IV

OBJECTIVE ASSESSMENT OF IMPROVEMENT AT 3 AND 6 WEEKS

\begin{tabular}{|c|c|c|c|c|c|c|c|}
\hline Group & & I & II & III & I & II & III \\
\hline \multirow{5}{*}{ Grade } & -1 & $4 \cdot 4$ & 4 & $8 \cdot 7$ & $4 \cdot 4$ & 12 & - \\
\hline & 0 & $47 \cdot 8$ & 40 & $30 \cdot 4$ & $30 \cdot 4$ & 32 & $26 \cdot 2$ \\
\hline & 1 & $43 \cdot 4$ & 52 & $52 \cdot 2$ & $47 \cdot 8$ & 44 & $43 \cdot 4$ \\
\hline & 2 & $4 \cdot 4$ & 4 & $8 \cdot 7$ & $17 \cdot 4$ & 8 & 30.4 \\
\hline & 3 & - & - & - & - & 4 & - \\
\hline Time (wks) & 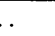 & & 3 & & & 6 & \\
\hline
\end{tabular}

gain". Only one subject in the whole experiment achieved a major gain, and this was in Group II.

The patients' impressions of their own progress at 6 weeks are shown in Table V. They closely approximate to those of the assessors, and are, in fact, identical for the untreated series.

TABLE V

PATIENTS' SUBJECTIVE EXPERIENCE OF IMPROVEMENT

\begin{tabular}{l|c|c|c|c}
\hline Group & & I & II & III \\
\hline & -1 & $4 \cdot 4$ & 12 & $4 \cdot 4$ \\
\hline \multirow{3}{*}{ Grade } & 0 & $30 \cdot 4$ & 20 & $13 \cdot 0$ \\
\cline { 2 - 4 } & 1 & $47 \cdot 8$ & 60 & $47 \cdot 8$ \\
\hline Time (wks) & 2 & $17 \cdot 4$ & 8 & $34 \cdot 8$ \\
\hline & 3 & - & - & - \\
\hline
\end{tabular}

Only thirteen out of the 71 subjects in the trial achieved a Class II overall improvement (a moderate gain). One of these was assessed as a major gain. four of these were in the untreated series, two in the partly treated, and seven in the fully treated group. The details of these thirteen subjects are set out in Table VI. It will be seen that there are apparently no common factors. They were of a wide age group
(12-71 yrs, mean $50 \cdot 5)$. There was a rather high proportion of early cases, six of the subjects being at Stage I of the disease (nearly 50 per cent.) as compared with 34 per cent. in the whole series. Only three subjects had a duration of disease exceeding 5 yrs (mean 4.9), as opposed to $7 \cdot 6$ yrs in the whole series. Pain, tenderness, weakness of grip, and swelling were not marked features in these subjects as a whole, but varied widely from case to case. The most noteworthy fact is that all derived considerable relief from pain, and twelve of the thirteen became completely pain-free, although tenderness remained, usually at a reduced level. Despite this, objective tests sometimes showed a poorer performance. These findings were no more marked in the treated than in the untreated subjects.

\section{Discussion}

Although the number of subjects studied in this investigation is small for analysis, they have been followed in detail. The changes occurring in the three groups were almost identical for the first 3 weeks of the test. After 6 weeks there was still little comparative difference in the local condition of the hands in the treated and control group; in fact the subjects who had the 3 weeks' course of treatment deteriorated and were subjectively worse in the end than the untreated patients. Such relief as did occur after the wax baths was of short duration, and the rapid return of skin temperature to its initial level also indicates that only temporary effects are produced.

Table III shows that a considerable improvement of pain in the hands can be expected from 6 weeks' institutional treatment, without any local therapy. Claims that any method of treatment produces improvement must take this into consideration.

TABLE VI

DETAILED PARTICULARS OF THIRTEEN PATIENTS WHO SHOWED IMPROVEMENT (AVERAGE OF THE TWO HANDS)

\begin{tabular}{|c|c|c|c|c|c|c|c|c|c|c|c|c|c|c|c|c|c|c|}
\hline \multirow{2}{*}{ Group } & \multirow{2}{*}{$\begin{array}{l}\text { Case } \\
\text { No. }\end{array}$} & \multirow{2}{*}{$\begin{array}{c}\text { Age } \\
(y r s)\end{array}$} & \multirow{2}{*}{ Sex } & \multirow{2}{*}{$\begin{array}{l}\text { Dura- } \\
\text { tion of } \\
\text { Disease }\end{array}$} & \multicolumn{2}{|c|}{ Disease } & \multicolumn{2}{|c|}{ Tenderness } & \multicolumn{2}{|c|}{ Grip } & \multicolumn{2}{|c|}{ Pain } & \multicolumn{2}{|c|}{ Swelling } & \multicolumn{2}{|c|}{ Dexterity } & \multirow{2}{*}{$\begin{array}{l}\text { Erythrocyte } \\
\text { Sedimenta- } \\
\text { tion Rate } \\
\text { (Westergren) } \\
\text { (initial) } \\
\text { (mm./hr) }\end{array}$} & \multirow{2}{*}{ Result } \\
\hline & & & & & Stage & Grade & Initial & Final & Initial & Final & Initial & Final & Initial & Final & Initial & Final & & \\
\hline I & $\begin{array}{l}28 \\
43 \\
54 \\
83\end{array}$ & $\begin{array}{l}56 \\
60 \\
53 \\
39\end{array}$ & $\begin{array}{l}\mathbf{F} \\
\mathbf{M} \\
\mathbf{F} \\
\mathbf{F}\end{array}$ & $\begin{array}{r}3 \\
2 \\
10 \\
1\end{array}$ & $\begin{array}{l}3 \\
2 \\
2 \\
1\end{array}$ & $\begin{array}{l}2 \\
2 \\
2 \\
2\end{array}$ & $\begin{array}{r}15 \\
10 \\
20 \\
5\end{array}$ & $\begin{array}{r}5 \\
2 \\
11 \\
2\end{array}$ & $\begin{array}{r}70 \\
100 \\
61 \\
85\end{array}$ & $\begin{array}{r}35 \\
175 \\
53 \\
112\end{array}$ & $\begin{array}{l}1 \\
0 \\
3 \\
0\end{array}$ & $\begin{array}{l}\mathbf{0} \\
0 \\
0 \\
0\end{array}$ & $\begin{array}{r}4 \\
10 \\
3 \\
6\end{array}$ & $\begin{array}{l}4 \\
8 \\
3 \\
4\end{array}$ & $\begin{array}{l}25 \\
31 \\
27 \\
22\end{array}$ & $\begin{array}{l}27 \\
39 \\
33 \\
28\end{array}$ & $\begin{array}{l}93 \\
60 \\
28 \\
14\end{array}$ & $\begin{array}{l}2 \\
2 \\
2 \\
2\end{array}$ \\
\hline II & $\begin{array}{r}8 \\
84\end{array}$ & $\begin{array}{l}57 \\
62\end{array}$ & $\begin{array}{l}\mathbf{M} \\
\mathbf{M}\end{array}$ & $\begin{array}{l}5 \\
1\end{array}$ & $\begin{array}{l}1 \\
1\end{array}$ & $\begin{array}{l}2 \\
2\end{array}$ & $\begin{array}{l}11 \\
14\end{array}$ & $\begin{array}{l}0 \\
1\end{array}$ & $\begin{array}{l}222 \\
250\end{array}$ & $\begin{array}{l}235 \\
238\end{array}$ & $\begin{array}{l}3 \\
0\end{array}$ & $\begin{array}{l}0 \\
0\end{array}$ & $\begin{array}{l}7 \\
5\end{array}$ & $\begin{array}{l}7 \\
5\end{array}$ & $\begin{array}{l}28 \\
28\end{array}$ & $\begin{array}{l}34 \\
32\end{array}$ & $\begin{array}{l}45 \\
25\end{array}$ & $\begin{array}{l}3 \\
2\end{array}$ \\
\hline III & $\begin{array}{r}3 \\
15 \\
18 \\
24 \\
85 \\
88 \\
91\end{array}$ & $\begin{array}{l}71 \\
12 \\
23 \\
64 \\
44 \\
54 \\
65\end{array}$ & $\begin{array}{l}\mathbf{F} \\
\mathbf{F} \\
\mathbf{F} \\
\mathbf{F} \\
\mathbf{F} \\
\mathbf{F} \\
\mathbf{F}\end{array}$ & $\begin{array}{r}1 \\
1 \\
1 \\
4 \\
19 \\
5 \\
11\end{array}$ & $\begin{array}{l}2 \\
1 \\
1 \\
1 \\
3 \\
2 \\
3\end{array}$ & $\begin{array}{l}2 \\
2 \\
2 \\
2 \\
2 \\
2 \\
3\end{array}$ & $\begin{array}{r}4 \\
10 \\
8 \\
19 \\
25 \\
12 \\
16\end{array}$ & $\begin{array}{r}4 \\
0 \\
2 \\
10 \\
18 \\
8 \\
7\end{array}$ & $\begin{array}{l}75 \\
43 \\
40 \\
66 \\
38 \\
80 \\
50\end{array}$ & \begin{tabular}{l|l}
70 & \\
73 & \\
70 & \\
88 & \\
50 & \\
90 & \\
85 &
\end{tabular} & $\begin{array}{l}2 \\
0 \\
1 \\
2 \\
9 \\
1 \\
1\end{array}$ & $\begin{array}{l}0 \\
0 \\
0 \\
0 \\
3 \\
0 \\
0\end{array}$ & $\begin{array}{l}1 \\
0 \\
0 \\
6 \\
5 \\
6 \\
6 \\
2\end{array}$ & $\begin{array}{l}1 \\
0 \\
0 \\
5 \\
4 \\
6 \\
2\end{array}$ & $\begin{array}{l}17 \\
31 \\
25 \\
25 \\
13 \\
30 \\
24\end{array}$ & $\begin{array}{l}22 \\
39 \\
32 \\
39 \\
18 \\
30 \\
37\end{array}$ & $\begin{array}{l}50 \\
40 \\
70 \\
62 \\
27 \\
80 \\
50\end{array}$ & $\begin{array}{l}2 \\
2 \\
2 \\
2 \\
2 \\
2 \\
2\end{array}$ \\
\hline
\end{tabular}


The close similarity between the patients' subjective impression of progress and that made by an observer using all the data obtained in a comprehensive assessment throws doubt on the value of the so-called objective tests in rheumatoid arthritis. Relying on a single "objective" or "subjective" test may be especially misleading. In all these tests the assessor must depend on the patients' co-operation, and this introduces a high "subjective" element (Harris, 1950).

Mandel (1954) compared objective and clinical assessments of progress with the patients' general impression, and reached the conclusion that the patients' impression is as satisfactory as the most objective of assessment techniques. This accords with our findings.

Coyer (1954) used citrate iontophoresis in fifteen subjects with rheumatoid arthritis, and has compared their progress with that of twenty similar subjects given galvanic hand baths. In the control group eighteen subjects had little or no relief, and strength of grip showed only a small increase.

In the citrate ionization group, thirteen of the fifteen claimed marked relief of pain and stiffness of the joints, lasting for 4-5 hrs after treatment. Grip strength improved markedly, with an average rise of over $100 \mathrm{~mm} . \mathrm{Hg}$ on the ergometer. This compares with an average rise of $12 \mathrm{~mm}$. $\mathrm{Hg}$ in our 6-week wax series.

The technique of wax baths used in this investigation has been practised in this hospital for at least 15 years and is widely used elsewhere. Paraffin-wax when first introduced was used as a continuous immersion bath, lasting between 20 and 30 minutes. The change in technique from baths to packs was probably due to the increased number of patients who can be treated in the same bath by dipping and packing, as compared with continuous immersion. An investigation of the use of this latter technique in treating the rheumatoid hand would appear to be necessary before discarding paraffin-wax baths.

\section{Summary}

(1) A comparative study of the progress of the hands in rheumatoid arthritis has been made in three groups of subjects:

(a) No local treatment of the hands (23 subjects).

(b) Paraffin-wax baths and packs, five times a week for 3 weeks ( 25 subjects).

(c) Paraffin-wax baths and packs, five times a week for 6 weeks (23 subjects).

(2) A comprehensive assessment was carried out initially and weekly in each group for 6 weeks.

(3) No difference was found between the three groups at 3 weeks, but at 6 weeks the group treated continuously with wax was slightly better.
(4) A study of patients who did improve did no indicate any method of selecting patients most likely to benefit from wax-bath treatment.

(5) Paraffin-wax hand baths are of little value i the treatment of rheumatoid arthritis.

We wish to acknowledge with thanks the help give by the staff of the Physiotherapy Department and the advice of Professor J. H. Kellgren.

\section{REFERENCES}

Coyer, A. B. (1954). Ann. phys. Med., 2, 16.
Harris, R. (1950). Brit. med. J., 2, 947.

Humphris, F. H. (1919). Med. Press, 108 n.s. (169 o.s.), 463.

Kovács, R. (1945). "Electrotherapy and Light Therapy", 5th ed,

p. 472. Kimpton, London.
Mandel, L. (1954). Thesis, University of Liverpool.

Steinbrocker, O., Traeger, C., and Batterman, R. (1949). J. Ameญ med. Ass., 140, 659.

\section{Bains de paraffine dans le traitement de l'arthrite rhumatismale}

RÉSUMÉ

(1) On a étudié le progrès comparatif des mains dañ్̂ l'arthrite rhumatismale dans trois groupes de sujets:

(a) Pas de traitement local des mains (25 sujets).

(b) Bain et enveloppement de paraffine, cinq fois par semaine pendant 3 semaines ( 25 sujets).

(c) Bain et enveloppement de paraffine, cinq fo $\mathbb{D}$ par semaine pendant 6 semaines ( 25 sujets).

(2) On effectuait une évaluation compréhensive initiale et hebdomadaire pendant 6 semaines dans toư les groupes.

(3) On n'a pas trouvé de différence entre les t\&o: groupes au bout de trois semaines, mais au bout de्sigr semaines le groupe traité continuellement par la parafine se trouvait un peu mieux que les deux autres.

(4) L'étude des ceux qui n'accusaient pas d'améliơ̆ tion n'a indiqué aucune méthode qui permette de chois يै土 des malades susceptibles de tirer avantage du traitemen par des bains de paraffine.

(5) On a conclu que les bains des mains dans paraffine sont peu utiles comme traitement de l'arthrit rhumatismale.

\section{Baños de parafina en el tratamiento de la artritis reumatoide \\ SUMARIO}

(1) Se procedió a un estudio comparado del progresiơ de las manos en la artritis reumatoide en tres grupos de sujetos:

(a) Sin tratamiento local alguno de las manos. (25 sujetos).

(b) Baños y envoltura de parafina, cinco veces pợ semana durante 3 semanas ( 25 sujetos).

(c) Baños y envoltura de parafina, cinco veces po्f semana durante 6 semanas ( 25 sujetos). (2) Se hizo uná avaluación comprensiva, inicial

(3) No se observó diferencia entre los tres grupos cabo de tres semanas, pero al cabo de seis semanas el grupo tratado continuamente con parafina encontrose algo mejor que los demás.

(4) El estudio de los que no acusaron mejoría no difo indicación alguna que permitiera la selección de l\& enfermos susceptibles de beneficiar del tratamiento cen baños de parafina.

(5) Se concluyó que los baños de manos en parafina no son muy útiles en el tratamiento de la artritis reumatoide. 